\title{
The spatial distribution pattern of heavy metal concentrations in urban soils - a study of anthropogenic effects in Berehove, Ukraine
}

Research Article

\author{
Tímea Vince ${ }^{1}$, György Szabó ${ }^{*}$, Zoltán Csoma², Gábor Sándor ${ }^{1}$, Szilárd Szabó \\ 1 Department of Landscape Protection and Environmental Geography, University of Debrecen, 4032 Debrecen, Egyetem tér 1., \\ Hungary \\ 2 Department of Biology, Ferenc Rákóczi II. Transcarpathian Hungarian Institute, 90202, Berehove, Ukraine \\ 3 Department of Physical Geography and Geoinformatics, University of Debrecen, 4032 Debrecen, Hungary
}

Received 30 November 2013; accepted 07 February 2014

\begin{abstract}
In the present study we examined the $\mathrm{Ba}, \mathrm{Cd}, \mathrm{Cr}, \mathrm{Cu}, \mathrm{Fe}, \mathrm{Mn}, \mathrm{Ni}, \mathrm{Pb}$ and $\mathrm{Zn}$ contamination levels of the soils of Berehove, a small city in West-Ukraine. As a first step we determined the spatial distribution of the heavy metal contents of the urban soils; then, by studying the land use structure of the city and by statistical analysis we identified the major sources of contamination; we established a matrix of correlations between the heavy metal contents of the soils and the different types of land use; and finally, we drew a conclusion regarding the possible origin(s) of these heavy metals. By means of multivariate statistical analysis we established that of the investigated metals, $\mathrm{Ba}, \mathrm{Cd}, \mathrm{Cu}, \mathrm{Pb}$ and $\mathrm{Zn}$ accumulated in the city's soils primarily as a result of anthropogenic activity. In the most polluted urban areas (i.e. in the industrial zones and along the roads and highways with heavy traffic), in the case of several metals $(\mathrm{Ba}, \mathrm{Cd}, \mathrm{Cu}, \mathrm{Pb}, \mathrm{Zn})$ we measured concentration levels even two or three times higher than the threshold limit values. Furthermore, $\mathrm{Cr}$, $\mathrm{Fe}$ and $\mathrm{Ni}$ are primarily of lithogenic origin; therefore, the soil concentrations of these heavy metals depend mainly on the chemical composition of the soil-forming rocks.
\end{abstract}

Keywords: heavy metal pollution $\cdot$ human impact $\cdot$ multivariate statistics $\cdot$ urban soils

(c) Versita sp. z o.o.

\section{Introduction}

The most frequent pollutants of urban soils are heavy metals. The pollutants accumulated on the surface can be transferred to the deeper soil layers and infiltrate into the groundwater - thus, they might become taken up by plants. To a certain extent, soils can adsorb

*E-mail: szabo.gyorgy@science.unideb.hu and bind these heavy metals, decreasing their harmful effects, but as a consequence of a possible change in soil characteristics (such as a decrease in $\mathrm{pH}$, etc.) previously accumulated heavy metals can become soluble rather abruptly, and thus, their toxic effects may be manifested [1, 2]. Polluted soils primarily endanger plants and soildwelling creatures; human health in general is directly at risk only if the soil is being accidentally ingested per os or per naso (through the nasal cavity). However, children in playgrounds are exposed to a much higher risk, because 
traces of soil or sand in the playground can easily get into their mouths from their hands [3-5]. In addition, consumption of both edible plants and food products of animal origin that are contaminated with heavy metals may threaten human health indirectly.

Even uncontaminated soils in their natural condition might contain heavy metals, which get into the soil during the weathering of the soil-forming rocks. In such cases the heavy metal contents depend on the type(s) of rock on which the soil formation occurred $[6,7]$.

The main sources of heavy metal contamination in urban soils are traffic, industrial activity, and household and industrial (toxic) waste. The heavy metals of traffic origin primarily pollute the atmosphere, but after being deposited they may also accumulate in the soil. Due to such pollution via the atmosphere, the heavy metal concentrations may increase not only in the immediate vicinity of the contamination source, but also in the soils of more remote urban parks and other green areas [8]. The most common heavy metals resulting from road traffic include $\mathrm{Pb}, \mathrm{Cd}, \mathrm{Zn}$ and $\mathrm{Cu}$. Formerly, lead $(\mathrm{Pb})$ was used as an additive to gasoline [6]. With the introduction of lead-free gasoline the $\mathrm{Pb}$ pollution has decreased significantly in the atmosphere, but not in the soils, where its ratio has remained high [9]. The mobility of lead is rather limited, which is why it stays in the soil for a relatively long time; therefore, pollution from the past still has an ongoing effect in the present [10-14]. The accumulation of $\mathrm{Cd}, \mathrm{Zn}$ and $\mathrm{Cu}$ along the roads is primarily due to the abrasion of tires and vehicle parts [11, 15].

The most significant industrial pollutions of the last century were the result of the exploitation and processing of ore reserves, as well as the burning of fossil fuels. For a long time no real attention was paid to the heavy metals that escaped into the natural environment, and so they often caused very serious environmental damage [16-18]. $\mathrm{Li}$ et al. [19] reported that a very large amount of heavy metals had accumulated in the soils of Shenyang, an industrial city in China, due to uncontrolled and excessive heavy metal discharges.

The publications regarding the heavy metal load of soils focus primarily on the large industrial centers and metropolises, and there are fewer papers investigating the situation in smaller cities and rural towns, even though similar problems may often arise in such places [20]. In their study, Chirenje et al. [21] investigated the $\mathrm{Pb}$ contamination levels of two cities with different traffic rates and population densities (Miami, 370,000 and Gainesville, 95,000 inhabitants). Based on their results, they established that Miami suffered a significantly higher level of pollution: its averaged urban value turned out to be $152 \mathrm{mg} \mathrm{kg}^{-1}$, whereas that of Gainesville was only
$39.6 \mathrm{mg} \mathrm{kg}^{-1}$. Nevertheless, in both cities $\mathrm{Pb}$ levels as high as about $1000 \mathrm{mg} \mathrm{kg}^{-1}$ were detected.

The existing studies of the environmental conditions of Ukraine have primarily investigated and described the most endangered areas of the country [22]. However, data on the conditions of the areas outside of such industrial regions are rather scarce. In our research we aimed to reduce this lack of information, by analyzing soil samples from a small city of 24,000 residents, Berehove in WestUkraine.

Our hypothesis was that types of land use significantly influence the investigated heavy metal concentrations. Our main goals were: 1) to explore the horizontal and vertical distribution of some selected elements in the soils of Berehove; 2) to reveal the source and the level of contamination; 3) to distinguish the lithogenic and anthropogenic origin of the studied trace elements; 4) to determine the risk raised by the possible contamination.

\section{Materials and methods}

\subsection{The sampling and analysis}

In July 2010 a total of 60 topsoil samples were collected from the area of Berehove. At each designated sampling location a representative (composite) sample was created from 5-8 individual samples. In the process of the designation of the sampling locations our aim was twofold: 1) to cover the whole area of the city, and 2) to ensure that the number of samples should represent the different location types with different rates of land use (such as roadside/green/agricultural areas, fallow land, gardens, courtyards, etc.) in proportion to their ratio in the total sampling area.

For the sake of the investigation of vertical changes in heavy metal concentrations, we created four boreholes, which were sampled at every $20 \mathrm{~cm}$. We drilled into the soil until we reached the ground-water level. From the four sections a total of 78 samples were collected.

The samples were stored in plastic bags, and transported to the laboratory of the Institute of Geosciences (University of Debrecen) for further analysis. First, the samples were pretreated by drying in an exsiccator at $60^{\circ} \mathrm{C}$, and the dehydrated soil samples were homogenized, after which the analysis of different soil characteristics was carried out. Besides the heavy metals $(\mathrm{Cd}, \mathrm{Cr}$, $\mathrm{Cu}, \mathrm{Fe}, \mathrm{Mn}, \mathrm{Ni}, \mathrm{Pb}, \mathrm{Zn}) \mathrm{Ba}$ was also included in the investigation, given its important toxicological effect. The metal contents of the soil samples were determined according to the MSZ-08-1722-3:1989 [23] with acidic digestion (cc. $\mathrm{HNO}_{3}+\mathrm{H}_{2} \mathrm{O}_{2}$ ). The measurements were carried out with a Perkin-Elmer Optima 5300 DV ICP- 


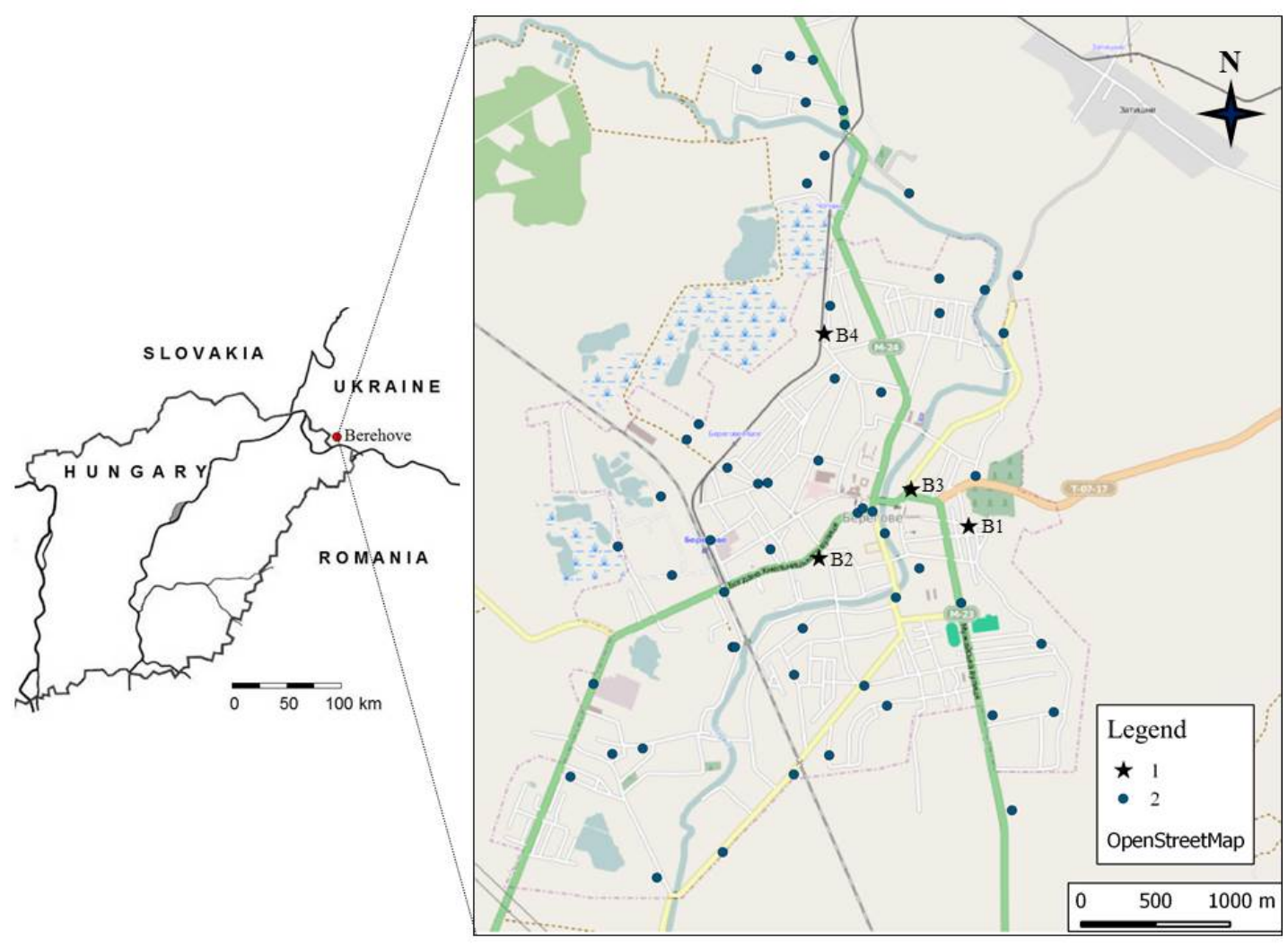

Figure 1. The geographical position of Berehove and the locations of the boreholes (1) and the surface samples (2).

OES appliance. As a reference for the evaluation of the heavy metal contents of the soil samples we applied the Hungarian "B contamination limit values" as detailed in joint decree 6/2009 (IV. 14.) of the KvVM-EüMFVM's [Hungarian Ministries of Environment, Healthcare and Agriculture, respectively], which is presently in force in Hungary [24]. Besides, characteristics of soils (e.g. soil types, sediments, $\mathrm{pH}$, clay minerals and humic substances such as inorganic and organic colloids) in the Transcarpathian Plain, where Berehove is situated, are very similar to the soils of the Great Hungarian plain, as they are the parts of the same physico-geographical unit. We also indicated the Dutch Target and Intervention Values [25], which is frequently cited in the scientific literature.

The soil $\mathrm{pH}$ was determined by an electric $\mathrm{pH}$ meter [26]; the granulometric composition was determined by sifting and sedimentation/siltation with a Köhnpipette [27], whereas the organic matter (OM) contents were determined by the Tyurin-method, which is based on the decomposition caused by potassium-dichromate, followed by titration with Mohr-salt [28].

\subsection{Statistical analysis}

The results of laboratory analysis were checked for normal distribution with the Shapiro-Wilk test, which showed that most of the variables were of normal distribution (except $\mathrm{Cd}, \mathrm{Mn}, \mathrm{Pb}$ and clay). Following this we applied $\log$ transformation with the formulae $\log (k+1)$, where $k$ represented the variables, to achieve a double aim: to standardize the variables which had different dimensions and to improve their normality [29]. In this way all variables followed normal distribution; furthermore, standardization was important for PCA [30].

In the case of samples collected from the topsoil, we revealed the correlation structure of the heavy metals using Principal Component Analysis (PCA) with Varimax rotation. We determined the number of principal components (PC) applying the Kaiser's criteria. Based 
on its low communality value $(<0.5)$ we excluded $\mathrm{Cu}$ from the variables $[31,32]$.

Component (PCs) regression scores were plotted on maps with Quantum GIS 1.8 [33] using OpenStreetMap [34] as a background. These maps visualized multiple contents in a grouped form as PCs constituted non-correlating factors and helped to explore the distribution of the element concentrations. Groups of maps (PC1-PC3) were formed using natural breaks. Also, original values of heavy metal concentrations were indicated on each map to help the interpretation of PCA scores.

The effect of land use was determined using ANOVA for all studied elements. In the case of those which were not normally distributed we controlled the results with the non-parametric Kruskal-Wallis test (as it is not sensitive to the distribution). Beside significance we also calculated the effect sizes $(r)$. If significance is above $p<0.05$, we judge the results as non-significant ones; however, sometimes the result depends only on 1-2 hundredths. If the significance is lower than 0.05 we accept that there are differences between the studied groups but we do not know their magnitude. Effect size ( $r$ ) specifically reflects the size of the difference in a standardized way $[35,36]$. 0 refers to a weak, 0.3 to a moderate effect, while 0.5 can be considered a large effect [36]. The Tukey test was applied to reveal the differences in heavy metal contents between the land use types.

\subsection{Study area}

Berehove is found in the western part of Ukraine (Figure 1), with 24,068 residents in 2008 [37]. The city is intersected by the $33 \mathrm{~km}$ long Canal Vérke, the water of which is heavily polluted by the urban waste waters. On the slopes of the Berehove Hills which border the city from the east, covered by rhyolite and andesite, and their respective tuffs, Luvisols of various thickness have formed, whereas on the flat areas to the west of Berehove, on the alluvial deposits of the Tisza River Fluvisols and Gleysol with different gleyization rates have developed. Their average humus content is $2.6 \%$, and in general they are quite acidic, with a $\mathrm{pH}$ of 4.0-4.7 [38, 39].

The hills around Berehove are rich in ore and in various raw minerals. The previous cultivation of the Nagymuzsaly area - which is about $2 \mathrm{~km}$ from the city and is known for gold-mining - may have affected the trace element contents of the urban soils. In the close vicinity of the city, on the western side of the hills, existing quarries of polymetallic ores (lead, zinc, copper, barite) are found, but their exploitation has ceased [40].

Today in Berehove there is hardly any industrial sector which could account for a substantial heavy metal pollution, with one possible exception being the ironworks in the western part of the city, which in the past decades, and especially in the Soviet era, provided a workplace for several hundred of the city's residents. However, nowadays the volume of production is significantly reduced.

On the other hand, motor-vehicle traffic can easily be a relevant pollution source, as the city is crossed by the Mukacheve - Berehove - Khust main road. In addition, the crossing point at Beregsurány - Astej, being only $8 \mathrm{kms}$ from the city, also contributes significantly to the heavy traffic in Berehove [41].

\section{Results}

\subsection{The physico-chemical characteristics of the topsoil}

The granulometrical composition in the soil samples of Berehove revealed a predominance of larger-sized mechanical elements, such as coarse sand and sand. The rate of the particles under $<0.02 \mathrm{~mm}$ only exceeded $50 \%$ in a few cases. Soils with clayey loam, which is quite typical of the areas surrounding the city, were only found in samples taken from a deeper plough land and a fallow area on the outskirts of the city. Those loam soil texture categories in which the dust and clay contents together constitute more than half of the total mechanical composition were also found both in arable fields and uncultivated fallows. In the above-mentioned soils the ratio of the clay fraction was higher in comparison to that of the other soil samples studied. On the other hand, in the soils from built-up areas the proportion of rougher granules (i.e. coarse and fine sand) was found to be much higher, more than $65 \%$ on average. The coarse granulometrical fraction had the highest proportion in the roadside and courtyard soil samples.

With regard to the $\mathrm{pH}$ of the urban soils it can be established that the values increase from the low (acidic) $\mathrm{pH}$ of the soils sampled from cultivated lands, through the neutral $\mathrm{pH}$ of the parks, fallow and small gardens, to the slightly alkaline (and sometimes definitely basic) $\mathrm{pH}$ of the roadside and courtyard samples.

The organic matter content of the studied soils varied over a relatively wide range; the lowest proportions were detected in the agricultural arable land samples, which also reflect the organic matter levels of the zonal soils surrounding the city. In the case of other types of land use, regardless of the great variation within each category, the mean organic matter contents were found to be nearly 
the same, but approximately twice as high as the average values in the zonal soils surrounding the city.

\subsection{Heavy metal contents in the topsoil}

Evaluation was performed on the basis of the Hungarian "B contamination limit values" [24]. Of the heavy metals studied $\mathrm{Ba}, \mathrm{Cd}, \mathrm{Cu}, \mathrm{Ni}, \mathrm{Pb}$ and $\mathrm{Zn}$ were found to exceed the limit values in the soils (Table 1$)$. In the case of $C d$, $\mathrm{Cu}, \mathrm{Pb}$ and $\mathrm{Zn}$ the detected maximum concentrations were approximately twice as high as the limit values. In regard to $\mathrm{Zn}$ about one third of the soil samples contained more zinc than the $200 \mathrm{mg} \mathrm{kg}^{-1}$ limit concentration. However, in the case of $\mathrm{Cd}$ we found only one sample with an extremely high concentration, whereas the values varied below the $1 \mathrm{mg} \mathrm{kg}^{-1}$ limit in all other locations.

Investigation of element concentrations by land use types revealed that $\mathrm{Ba}, \mathrm{Ni}$ and $\mathrm{Zn}$ showed different accumulations. Although all these elements had significant differences among land use types, effect sizes reflected that it had a moderate effect only in the case of $\mathrm{Zn}$, in two other cases the effect ( $r$ ) was weak (Table 2).

Based on the post hoc analysis (Tukey test), courtyard and agricultural land differed significantly (the latter had smaller concentrations) in the case of $\mathrm{Ba}$ and $\mathrm{Zn}$; furthermore, agricultural land had significantly smaller concentrations than gardens in the case of $\mathrm{Zn}$. Zn content also differed $(p<0.05)$ in gardens and fallow land, too. Besides, soils in parks had a significantly higher $\mathrm{Ni}$ content than that on roadsides (Table 3).

Furthermore, $\mathrm{Cd}, \mathrm{Cu}$ and $\mathrm{Pb}$ had relevantly, but not significantly, lower concentrations in the agricultural lands outside the city compared to the other land use types (see Table 1). In the inner part of the city courtyards had the highest values for $\mathrm{Ba}, \mathrm{Mn}, \mathrm{Pb}$ and $\mathrm{Zn}$.

\subsection{Vertical distribution of the investigated elements}

Two of the four boreholes were found in the city center and the others were in the outskirts of Berehove. Considering the correlation relations and the vertical distribution of the metals, we distinguished two groups. $\mathrm{Cr}, \mathrm{Fe}$ and $\mathrm{Ni}$ belonged to the first group, in which the concentrations were smaller in the topsoil and had a tendency to increase in the deeper layers (e.g. B2, Figure 2). These elements had strong correlations $\left(r_{\mathrm{Cr}-\mathrm{Fe}}=0.80, r_{\mathrm{Cr}-\mathrm{Ni}}=0.76\right.$, $\left.r_{\mathrm{Fe}-\mathrm{Ni}}=0.80, p<0.01\right)$; furthermore, they also correlated with clay $\left(r_{\text {Clay-Cr }}=0.81, r_{\text {Clay-Fe }}=0.73, r_{\text {Clay- } \mathrm{Ni}}=0.63\right.$, $p<0.01)$. Ba, $\mathrm{Cd}, \mathrm{Cu}, \mathrm{Pb}$ and $\mathrm{Zn}$ constituted the other group, those where the concentration was the highest in the topsoil and relevantly lower in the deeper layers
(Figure 3). Cd was not plotted since it was detectable only in the surface layers. These elements had similar vertical distribution patterns and had strong correlations $\left(r_{\mathrm{Ba}-\mathrm{Cd}}=0.56, r_{\mathrm{Ba}-\mathrm{Cu}}=0.75, r_{\mathrm{Ba}-\mathrm{Pb}}=0.81, r_{\mathrm{Ba}-\mathrm{Zn}}=0.82\right.$, $r_{\mathrm{Cd}-\mathrm{Cu}}=0.56, r_{\mathrm{Cd}-\mathrm{Pb}}=0.62, r_{\mathrm{Cd}-\mathrm{Zn}}=0.64, r_{\mathrm{Cu}-\mathrm{Pb}}=0.83$, $\left.r_{\mathrm{Cu}-\mathrm{Zn}}=0.84, r_{\mathrm{Pb}-\mathrm{Zn}}=0.91 ; p<0.01\right)$. In this case, organic matter content was the dominant influencing factor of the concentration as was reflected by the correlation coefficients: $r_{\mathrm{OM}-\mathrm{Ba}}=0.74, r_{\mathrm{OM} . \mathrm{Cd}}=0.67, r_{\mathrm{OM} \text { - } \mathrm{Cu}}=0.56$, $r_{\mathrm{OM} . \mathrm{Pb}}=0.64, r_{\mathrm{OM}}-\mathrm{Zn}=0.72$. Based on the vertical distribution, $\mathrm{Mn}$ was not classified in the above mentioned groups.

\subsection{Multivariate analysis of the heavy metal concentrations}

We reduced the initial number of variables to three PCs which accounted for $80.8 \%$ of the total variance, and sampling adequacy was acceptable ( $\mathrm{KMO}=0.632)$. PC1 was defined by $\mathrm{Cr}, \mathrm{Ni}$ and $\mathrm{Fe}$, indicating that their concentrations changed (decreased or increased) together (Table 4). The same phenomenon was observed in the case of PC2 which was defined by $\mathrm{Zn}, \mathrm{Pb}, \mathrm{Ba}$ and $\mathrm{Cd}$; due to their strong positive correlations, these concentrations changed together in the same direction. PC3 corresponded with only the Mn concentration itself (as this element accounted for only $13 \%$ of the total variance, and in this concentration does not pose a risk to human health, we omitted it from the analyses). This approach enabled us to plot the concentrations on maps, indicating the areas where these elements had higher/lower concentrations (Figure 4, Figure 5).

$\mathrm{Cr}$, Fe and $\mathrm{Ni}$ formed the PC1, which accounted for $36.5 \%$ of the total variance. These elements were found to be in a significant, strong, positive correlation with each other, indicating that their concentrations would change in the same direction $\left(r_{\mathrm{Cr}-\mathrm{Ni}}=0.86 ; r_{\mathrm{Cr}-\mathrm{Fe}}=0.772\right.$; $\left.r_{\mathrm{Fe}-\mathrm{Ni}}=0.754 ; p<0.01\right)$. The highest and lowest $\mathrm{Cr}$ and $\mathrm{Ni}$ concentrations were found at the same locations. The Fe concentrations changed in a similar way, following the same pattern: where $\mathrm{Cr}$ and $\mathrm{Ni}$ were in the highest and lowest concentration, Fe values were also high and low, respectively. The ratio of the silt and clay fraction positively correlated with all three elements $\left(r_{\text {silt- } \mathrm{Cr}}=\right.$ $0.577 ; r_{\text {silt-Fe }}=0.485 ; r_{\text {silt-Ni }}=0.481 ; r_{\text {clay-Cr }}=0.533$; $\left.r_{\text {clay-Fe }}=0.415 ; r_{\text {clay-Ni }}=0.462 ; p<0.01\right)$. The highest values of the group were measured in samples originating from the northern and western areas of the city, as well as from the outskirts and suburbs (primarily collected from fallow lands and fields used for agriculture).

PC2 included four elements ( $\mathrm{Ba}, \mathrm{Cd}, \mathrm{Pb}, \mathrm{Zn})$, which also showed strong positive correlations with each other 
Table 1. Effect of land use on element concentrations based on the results of variance analysis (highlighted in bold: $p<0.05$ ).

\begin{tabular}{|c|c|c|c|c|c|c|c|c|c|c|}
\hline & $\mathrm{N}^{d}$ & $\mathrm{Ba}$ & Cd & $\mathrm{Cr}$ & $\mathrm{Cu}$ & $\mathrm{Fe}$ & Mn & $\mathrm{Ni}$ & $\mathrm{Pb}$ & Zn \\
\hline Mean & 60 & 155.9 & 0.30 & 21 & 45.1 & 17114 & 559.3 & 26.7 & 36.1 & 171.5 \\
\hline Minimum & 60 & 67.8 & 0.04 & 8.2 & 15.3 & 10141 & 173.3 & 10 & 7.9 & 40.9 \\
\hline Maximum & 60 & 409.8 & 2.96 & 46.4 & 158.3 & 24441 & 1144.8 & 51.8 & 206.2 & 434.6 \\
\hline SD & 60 & 67.2 & 0.38 & 6 & 29.1 & 3298 & 187 & 7.5 & 30.8 & 99.6 \\
\hline \multicolumn{11}{|c|}{ Landuse type (mean $\pm \mathrm{SD}$ ) } \\
\hline Agr. land & 6 & $103 \pm 10$ & $0.15 \pm 0.1$ & $22.9 \pm 4.3$ & $37.1 \pm 24.1$ & $17895 \pm 3050$ & $620 \pm 120$ & $27.0 \pm 5.1$ & $16.9 \pm 4.3$ & $78 \pm 28$ \\
\hline Park & 10 & $189 \pm 81$ & $0.56 \pm 0.8$ & $22.2 \pm 9.4$ & $33.1 \pm 12.2$ & $17053 \pm 3537$ & $557 \pm 206$ & $30.5 \pm 10$ & $29.8 \pm 14.4$ & $171 \pm 84$ \\
\hline Fallow & 9 & $125 \pm 27$ & $0.16 \pm 0.1$ & $24.1 \pm 5.8$ & $68.9 \pm 48.6$ & $18359 \pm 3691$ & $434 \pm 128$ & $27.7 \pm 6.5$ & $42.0 \pm 32$ & $123 \pm 63$ \\
\hline Garden & 12 & $157 \pm 37$ & $0.36 \pm 0.2$ & $21.2 \pm 2.8$ & $48.6 \pm 19.4$ & $17935 \pm 2533$ & $625 \pm 807$ & $28.6 \pm 5.3$ & $32.1 \pm 18.8$ & $242 \pm 115$ \\
\hline Courtyard & 7 & $202 \pm 99$ & $0.32 \pm 0.1$ & $20.2 \pm 6.4$ & $41.9 \pm 14.1$ & $16687 \pm 4377$ & $669 \pm 292$ & $28.0 \pm 8.2$ & $55.4 \pm 63.3$ & $247 \pm 99$ \\
\hline Roadside & 16 & $152 \pm 61$ & $0.22 \pm 0.1$ & $18.0 \pm 3.5$ & $41.1 \pm 26.5$ & $15728 \pm 2241$ & $511 \pm 140$ & $21.6 \pm 4.8$ & $38.6 \pm 21.4$ & $148 \pm 69$ \\
\hline $\mathrm{HCLV}^{a}$ & & 250 & 1 & 75 & 75 & - & - & 40 & 100 & 200 \\
\hline DTV $^{b}$ & & 160 & 0,8 & 100 & 36 & - & - & 35 & 85 & 140 \\
\hline $\mathrm{DIV}^{c}$ & & 625 & 12 & 380 & 190 & - & - & 210 & 530 & 720 \\
\hline
\end{tabular}

$a$ Hungarian Contamination "B" Limit Value, [23]

$b$ Dutch Target Value, [24]

c Dutch Intervention Value, [24]

$d$ number of samples

Table 2. Basic statistics of the investigated element contents $\left(\mathrm{mg} \mathrm{kg}^{-1}\right)$ in top-soil (in case of all samples and in the groups of land use types).

\begin{tabular}{lll}
\hline & Sig. & effect size $(r)$ \\
\hline $\mathrm{Ba}$ & 0.040 & 0.19 \\
$\mathrm{Cd}$ & 0.169 & 0.13 \\
$\mathrm{Cr}$ & 0.191 & 0.12 \\
$\mathrm{Cu}$ & 0.122 & 0.15 \\
$\mathrm{Fe}$ & 0.399 & 0.08 \\
$\mathrm{Mn}$ & 0.083 & 0.16 \\
$\mathrm{Ni}$ & 0.042 & 0.19 \\
$\mathrm{~Pb}$ & 0.308 & 0.10 \\
$\mathrm{Zn}$ & 0.001 & 0.30 \\
\hline
\end{tabular}

$\left(r_{\mathrm{Ba}-\mathrm{Cd}}=0.608 ; r_{\mathrm{Ba}-\mathrm{Pb}}=0.539 ; r_{\mathrm{Ba}-\mathrm{Zn}}=0.646 ; r_{\mathrm{Cd}-\mathrm{Pb}}=\right.$ $\left.0.487 ; r_{\mathrm{Cd}-\mathrm{Zn}}=0.768 ; r_{\mathrm{Pb}-\mathrm{Zn}}=0.591 ; p<0.01\right)$. The closest correlation was found between $\mathrm{Zn}$ and $\mathrm{Cd}$. Of the soil characteristics, the organic matter contents showed a positive significant correlation with all four elements in this group $\left(r_{\mathrm{OM} . \mathrm{Ba}}=0.483 ; r_{\mathrm{OM} . \mathrm{Cd}}=0.525 ; r_{\mathrm{OM} . \mathrm{-Pb}}=\right.$ $\left.0.717 ; r_{\mathrm{OM} . \mathrm{Zn}}=0.643 ; p<0.01\right)$. The highest values of the group were measured in samples originating from around the central and northwest (industrial) urban areas.
PC3 consisted only of Mn. It correlated with the concentrations of iron $\left(r_{\mathrm{Mn}-\mathrm{Fe}}=0.419\right)$ and barium $\left(r_{\mathrm{Mn}-\mathrm{Ba}}=0.397, p<0.01\right)$, as well as with cadmium $\left(r_{\mathrm{Mn}-\mathrm{Cd}}=0.255\right)$ and nickel $\left(r_{\mathrm{Mn}-\mathrm{Ni}}=0.281\right), p<0.05$. The highest values were found in samples originating from the northern areas of the city, and along the road that runs from Berehove towards the crossing point between Ukraine and Hungary at Astej-Beregsurány.

\section{Discussion}

For a proper evaluation of the results we must know the origin of the heavy metals studied. Although all the heavy metals measured are also naturally present in the soils, anthropogenic effects may significantly increase their concentrations $[42,43]$. Their origin can be deduced, for example, on the basis of their vertical distribution. Those metals which reach maximum concentration in the topsoil layers, with a significantly lower concentration in the deeper strata, have originated primarily from sources of anthropogenic activity - as opposed to those heavy metals which reach their maximum concentration in deeper soil layers, which would indicate that these trace elements are primarily of lithogenic origin, and human (anthropogenic) activity has probably played little or no role in their 
Table 3. Mean differences between land use types (highlighted with bold: $p<0.05$ ).

\begin{tabular}{|c|c|c|c|c|c|c|c|}
\hline $\begin{array}{l}\text { Land use } \\
\text { (i) }\end{array}$ & $\begin{array}{l}\text { Land use } \\
\text { (i) }\end{array}$ & $\begin{array}{c}\text { Mean difference } \\
\left(\mathrm{i}-\mathrm{j} ; \mathrm{mg} \cdot \mathrm{kg}^{-1}\right)\end{array}$ & Sig. & $\begin{array}{c}\text { Mean difference } \\
\left(\mathrm{i}-\mathrm{j} ; \mathrm{mg} \cdot \mathrm{kg}^{-1}\right)\end{array}$ & Sig & $\begin{array}{c}\text { Mean difference } \\
\left(\mathrm{i}-\mathrm{j} ; \mathrm{mg} \cdot \mathrm{kg}^{-1}\right)\end{array}$ & Sig \\
\hline \multirow[t]{5}{*}{ Roadside } & Courtyard & -49.35 & 0.53 & -6.39 & 0.36 & -98.65 & 0.15 \\
\hline & Garden & -4.33 & 1.00 & -6.98 & 0.12 & -94.35 & 0.07 \\
\hline & Agr. land & 49.35 & 0.59 & -5.37 & 0.61 & 69.84 & 0.56 \\
\hline & Park & -36.43 & 0.72 & -8.92 & 0.03 & -23.12 & 0.99 \\
\hline & Fallow & 27.63 & 0.90 & -6.15 & 0.31 & 25.26 & 0.98 \\
\hline \multirow[t]{4}{*}{ Courtyard } & Garden & 45.02 & 0.68 & -0.60 & 1.00 & 4.30 & 1.00 \\
\hline & Agr. land & 98.70 & 0.05 & 1.02 & 1.00 & 168.49 & 0.01 \\
\hline & Park & 12.92 & 1.00 & -2.54 & 0.98 & 75.53 & 0.50 \\
\hline & Fallow & 76.98 & 0.18 & 0.24 & 1.00 & 123.90 & 0.07 \\
\hline \multirow[t]{3}{*}{ Garden } & Agr. land & 53.69 & 0.55 & 1.62 & 1.00 & 164.19 & 0.01 \\
\hline & Park & -32.09 & 0.85 & -1.94 & 0.99 & 71.23 & 0.41 \\
\hline & Fallow & 31.97 & 0.86 & 0.83 & 1.00 & 119.60 & 0.03 \\
\hline \multirow[t]{2}{*}{ Agr. land } & Park & -85.78 & 0.11 & -3.56 & 0.93 & -92.95 & 0.32 \\
\hline & Fallow & -21.72 & 0.99 & -0.78 & 1.00 & -44.58 & 0.93 \\
\hline Park & Fallow & 64.06 & 0.26 & 2.77 & 0.96 & 48.37 & 0.83 \\
\hline
\end{tabular}
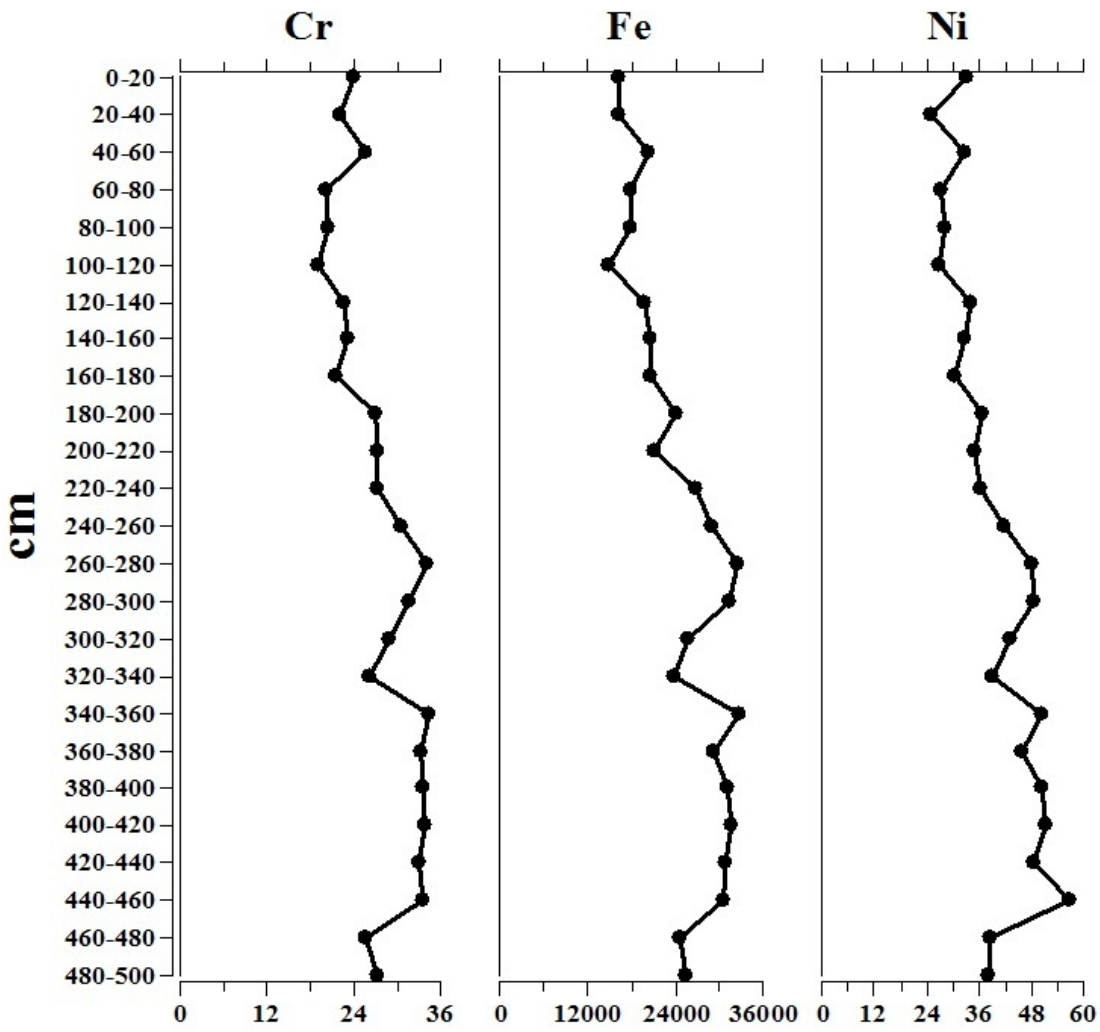

Figure 2. Vertical distribution of $\mathrm{Cr}$, $\mathrm{Fe}$ and $\mathrm{Ni}$ in the borehole $2\left(\mathrm{~B} 2 ; \mathrm{mg} \mathrm{kg}^{-1}\right)$. 

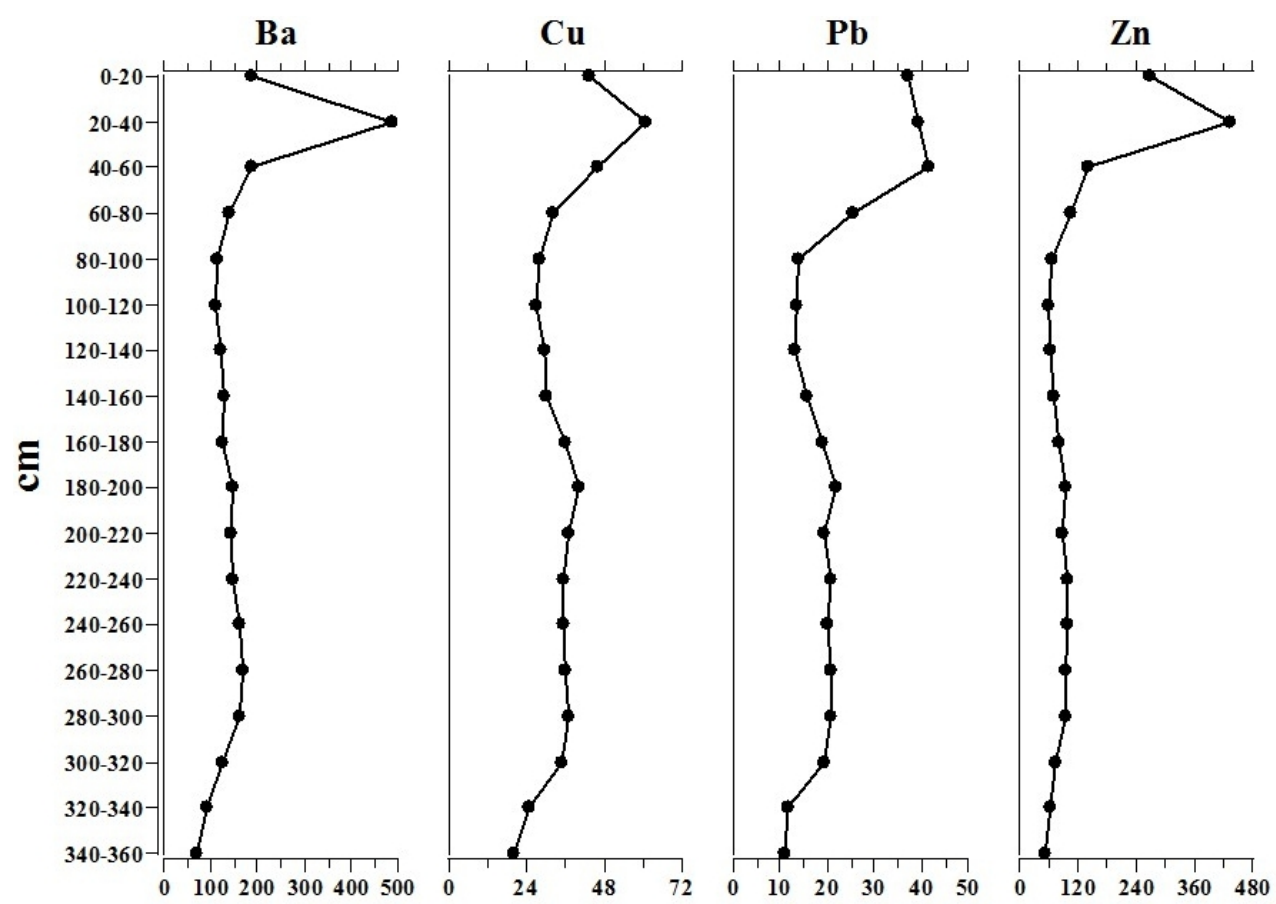

Figure 3. Vertical distribution of $\mathrm{Ba}, \mathrm{Cu}, \mathrm{Pb}$ and $\mathrm{Zn}$ in the borehole $4\left(\mathrm{~B} 4 ; \mathrm{mg} \mathrm{kg}^{-1}\right)$.

Table 4. Rotated principal component matrix of the investigated elements' concentrations.

\begin{tabular}{llll}
\hline & PC1 & PC2 & PC3 \\
\hline $\lg \mathrm{Cr}$ & 0.963 & & \\
$\lg \mathrm{Ni}$ & 0.932 & & \\
$\lg \mathrm{Fe}$ & 0.895 & & \\
$\lg \mathrm{Zn}$ & & 0.881 & \\
$\lg \mathrm{Pb}$ & & 0.801 & \\
$\lg \mathrm{Ba}$ & & 0.706 & \\
$\lg \mathrm{Cd}$ & & 0.691 & \\
$\lg \mathrm{Mn}$ & & & 0.937 \\
Variance explained (\%) & 36.5 & 31.2 & 13.1 \\
\hline
\end{tabular}

accumulation $[44,45]$.

Based on the results of the principal component analysis, $\mathrm{Cr}, \mathrm{Fe}$ and $\mathrm{Ni}$ were classified to PC1. Xia et al.'s [46] findings were similar: they established that the $\mathrm{Cr}$ and $\mathrm{Ni}$ concentrations in the soils of Beijing are similar to the background concentrations, and their spatial distribution was affected by natural (rather than anthropogenic) sources. Huang et al. [47], who studied the heavy metals in the soils of Jiangsu province, China, reached the same conclusion. Conducting PCA they also found that $\mathrm{Fe}, \mathrm{Ni}$ and $\mathrm{Cr}$ belonged to the same group. They also established that these metals were primarily of lithogenic origin, and their concentrations were determined by the soil forming (base) rock.

In our case, correlation studies revealed a relatively strong positive correlation $(p<0.01)$ with the fine fraction (i.e. silt and clay). The proportion of coarse fraction became more marked nearer the urban center, whereas at the same time, the concentrations of these metals decreased. According to our assumption these heavy metals originated not from anthropogenic but from lithogenic sources, and their distribution was influenced primarily by the granulometric composition of the soil, or to be more specific, the ratio of the fine fraction and by the chemical composition of the soil forming rock. This assumption is supported by the examination of the boreholes of Berehove, which revealed that in the case of the heavy metals belonging to the first group, the maximum concentrations were not found in the topsoils but in deeper layers of the sample sections; in other words, they showed the vertical distribution pattern typical of the metals with lithogenic origin (Figure 2). 

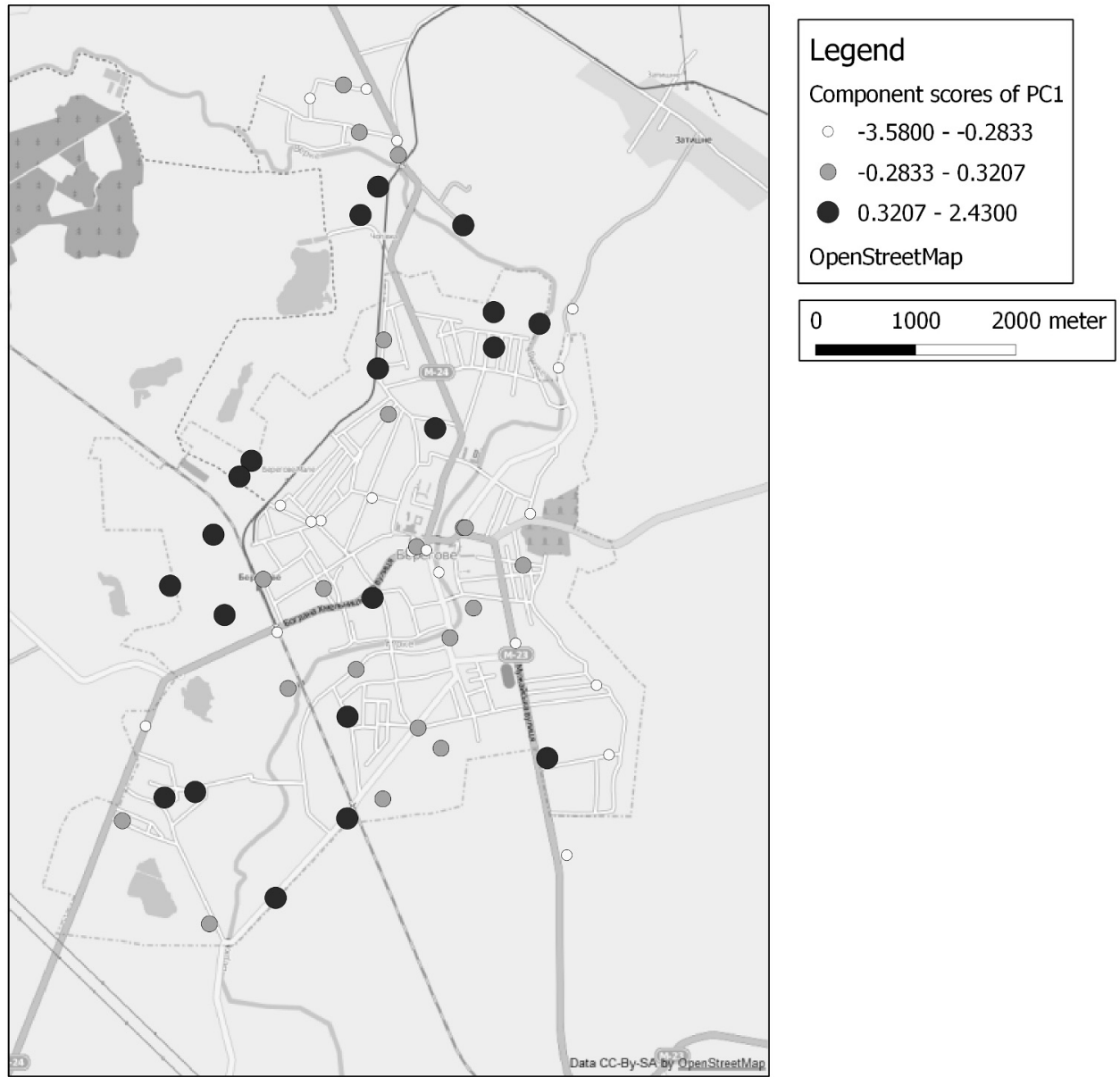

Figure 4. Factor scores of $\mathrm{PC} 1$, indicating the relative concentrations of $\mathrm{Cr}$, $\mathrm{Fe}$ and $\mathrm{Ni}(\mathrm{Cr}$ 0: 8.51-17.3; •: 17.4-23.05; •: 23.06-46.43; $\mathrm{Fe}$ ०:10515-15640; •: 15641-18615; •: 18616-24440; Ni ०:10.0-27.3; •: 27.4-28.5; •: 28.6-51.8; $\mathrm{mg} \mathrm{kg}^{-1}$ ).

Despite the fact that the ironworks in the industrial zone contributed to a certain extent to the accumulation of Fe in the topsoil, this still did not represent a significant increase, since the natural Fe content of the soil is higher by several orders of magnitude than that of the other studied metals. This being so, the extra Fe accumulation in the topsoil that resulted from anthropogenic sources is practically negligible in comparison to the original Fe concentration.

The metals grouped in PC2 (Ba, Cd, Pb, Zn) originated primarily from anthropogenic sources, which was supported by the results of their vertical distribution analysis. As we could see above (Figure 3), these metals reached the highest concentration in the topsoil.

Based on the spatial distribution analysis of the elements we identified the possible sources of contamination. The industrial zone is located at the west/northwest parts of Berehove. In these areas $\mathrm{Zn}, \mathrm{Pb}$ and $\mathrm{Cu}$ concentrations were high at several sampling points, and often even exceeded the limit values. The area became contaminated most probably by the industrial activity (iron- and metal-working, majolica production) of recent times, and especially of the past few decades. Similarly to our study, several other authors reached the same conclusion that industrial emissions may be a major source of the topsoil accumulation of $\mathrm{Zn}, \mathrm{Pb}$ and $\mathrm{Cu}$ [48-51].

In the central urban areas $\mathrm{Pb}, \mathrm{Zn}$ and $\mathrm{Ba}$ concentrations were significantly higher, which was most probably due to the heavy traffic in the city center. Several authors regard motor-vehicle traffic as the single most important source of $\mathrm{Pb}$ and $\mathrm{Zn}$ contamination [13, 46, 52]. In Ukraine, in accordance with the decree No. 2786-III [53], the 

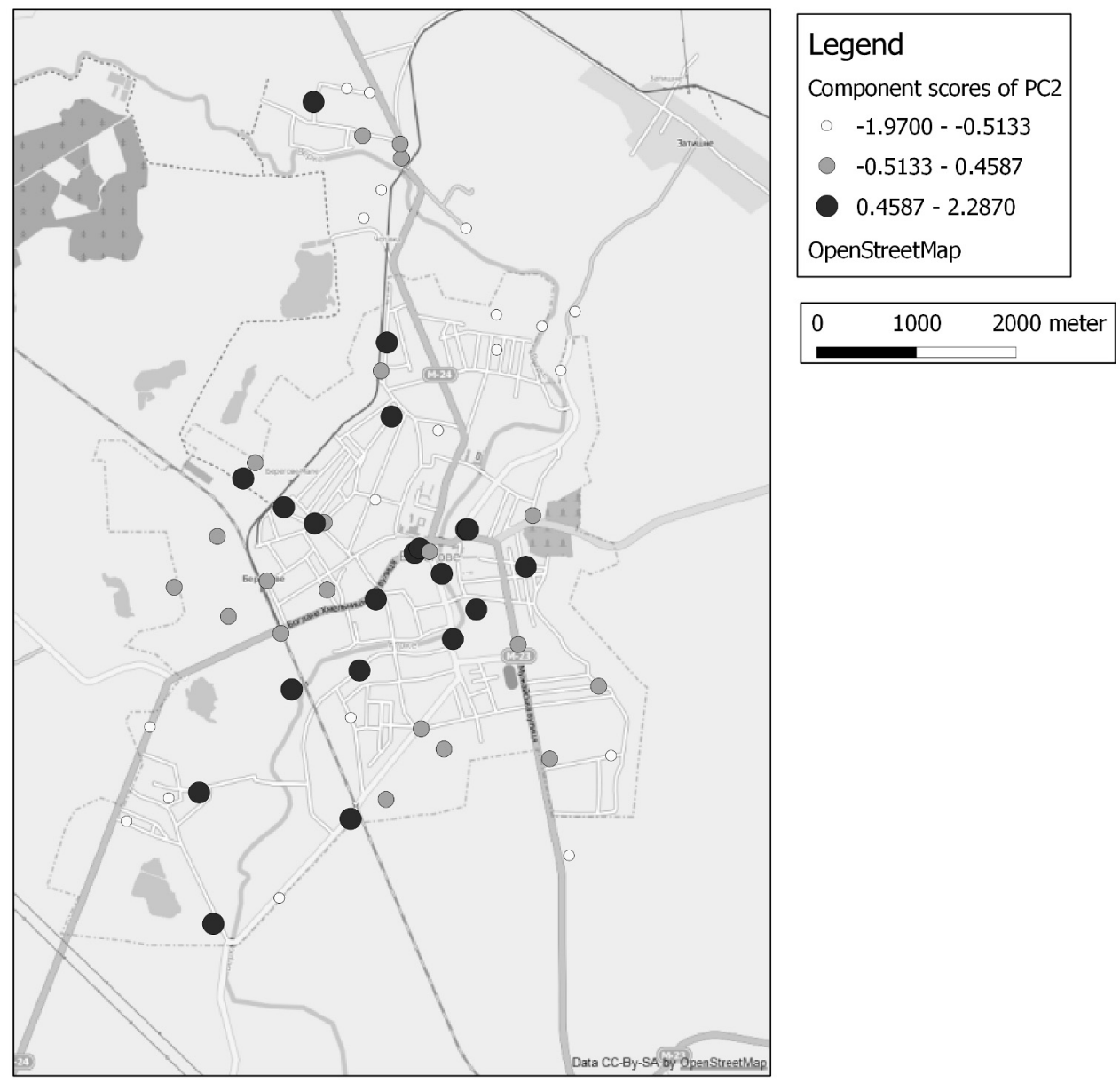

Figure 5. Factor scores of $\mathrm{PC2}$, indicating the relative concentrations of $\mathrm{Ba}, \mathrm{Cd}, \mathrm{Pb}$ and $\mathrm{Zn}(\mathrm{Ba} \circ:$ : 67.8-95.8; •: 95.9-188.8; •: 188.9-409.8; Cd ०: 0.03-0.13; •: 0.14-0.18; •: 0.19-2.95; Pb o: 7.86-31.4; •: 31.5-37.2; •: 37.3-206.2; Zn ०: 40.9-106.1; •: 106.2-267.1; •: 267.2-434.6; $\mathrm{mg} \mathrm{kg}^{-1}$ ).

importation and distribution of leaded gasoline or any lead-containing additive for sale in gas-stations has been forbidden since 1st January 2003. However, previously the lead originating from leaded gasoline could have accumulated in the roadside soils over several decades. Furthermore, lead has relatively limited mobility, and therefore it can remain and become concentrated in the soils [10, 54-56]. These results are in good accordance with the findings of other authors, who demonstrated that lead concentrations are significantly higher in roadside soils $[6,57]$. The $C d$ concentration was extremely high in only one sampling point, which - according to our investigation - was caused by the sludge that was washed ashore from the canal crossing the city.

Since organic matter increases the heavy metal-adsorbing capacity of soils [58-60], heavy metals, as a result of contaminations, could have easily accumulated in the top layers which were originally richer in humus. This was further supported by the results of the correlation analysis, according to which the concentrations of the elements belonging to the second group were in a strong positive correlation with the organic matter content of the soils.

Considering land use, agricultural lands had the lowest values regarding those elements derived from anthropogenic sources in the outskirts, while the same elements had higher concentrations in the inner part of the city. This can be explained by the above mentioned pollution sources; besides, plants in agricultural lands uptake trace elements (e.g. Zn, Cu) and, without replacement, decrease their concentration in the soil. 
Heavy metal pollution of soils represents a real risk for the inhabitants of Berehove. The concentrations of some toxic elements $(\mathrm{Ba}, \mathrm{Cu}, \mathrm{Pb}, \mathrm{Zn})$ were above the limit value in the topsoil samples in several cases. The fine dust particles which get into the air from the soil surface can enter the human body directly through the nose or mouth. From children's hands the fine soil particles can also get into their mouth. We often measured concentrations above the limit value for $\mathrm{Ba}, \mathrm{Cu}$, and $\mathrm{Zn}$ in the root areas of vegetable plants (Figure 3) which could also be a risk, because these toxic elements can get into the human body via the edible parts of plants $[61,62]$. Although the concentrations of these toxic elements are not extremely high, it is reasonable to inform the inhabitants regarding the possible dangers.

Consequently, we can conclude that with regard to the heavy metals studied, the soils of Berehove can be categorized as moderately contaminated. It is extremely important to know the heavy metal concentrations and their health risks in large cities (e.g. Shanghai, Mexico City) $[13,51]$ : which are the crucial metals, what are the emission sources and the magnitude of accumulation. However, most people live in smaller cities and they are also exposed to different environmental problems. Heavy metals emitted by industry, traffic or other sources (e.g. heating systems) are possible risk factors and we have to know the level of pollution. Our results are in strong agreement with other authors [20,63-65] who have studied different sized cities (without dominant industrial production but with a relevant traffic load) and reinforce the idea that generally there are moderate levels of pollution with possible local problems.

\section{Conclusions}

Our hypothesis, that land use types significantly influence the heavy metal concentrations investigated, was not verified unambiguously, since there were only three metals (Ba, Ni, Zn), with significant differences among some land use types.

Based on the multivariate statistical analysis and the vertical distribution of studied elements we established that $\mathrm{Ba}, \mathrm{Cd}, \mathrm{Cu}, \mathrm{Pb}$ and $\mathrm{Zn}$ accumulated in the urban soils primarily because of anthropogenic effects. In the case of these metals we measured concentration values that were often higher than the threshold limits. Contrarily, the $\mathrm{Cr}, \mathrm{Ni}$ and $\mathrm{Fe}$ concentrations were characterized by a tendency to increase downwards towards the deeper layers, which results from their lithogenic origin. These elements were in the same group in the PCA.

By studying the spatial distribution of the contamination and the land use structure of the area we successfully identified the main contamination sources. One of the biggest sources of pollution in the city is traffic; nevertheless, it does not cause extremely high pollution, even despite the extensive and prolonged use of leaded gasoline and lead-containing additives in the past. The contamination originating from industry was also found to be important in the city, but again, the $\mathrm{Pb}, \mathrm{Zn}$ and $\mathrm{Cu}$ contamination - which often exceeds the concentration limits - can be traced back to past industrial activities, as nowadays these factories produce on a much smaller scale and with significantly lower capacity.

The city's most heavily contaminated areas may impose a certain health risk on the population, especially if the residents consume the fruits and vegetables grown in the local kitchen-gardens.

To summarize, we can conclude that the soils of Berehove are moderately contaminated by heavy metals, but the extent of this contamination falls way behind the levels typical of more industrialized areas in Ukraine.

\section{Acknowledgements}

This paper was supported by the TÁMOP-4.2.2/B-10/12010-0024. The project was co-financed by the European Union and European Social Fund.

\section{References}

[1] Simon L., The contamination and cleaning of soils, Budapest, 1999 (in Hungarian)

[2] Sterckeman T., Dounay F., Proix N., Fourrier H., Vertical distribution of $\mathrm{Cd}, \mathrm{Pb}$ and $\mathrm{Zn}$ in soils near smelters in the North of France, Environ. Pollut., 107, 2000, 377-389

[3] Mezősi G., Mucsi L., Farsang A., The role of urban ecology in territorial planning, as exemplified by Szeged city, Alföldi Tanulmányok, 17, 1999, 74-93 (in Hungarian)

[4] Möller A., Müller H. W., Abdullah A., Abdelgawad G., Utermann J., Urban soil pollution in Damascus, Syria: concentrations and patterns of heavy metals in the soils, Geoderma, 124, 2005, 63-71, DOI: 10.1016/j.geoderma.2004.04.003

[5] Yamamoto N., Takahashi Y., Yoshinaga J., Tanaka A., Shibata Y., Size distribution of soil particles adhered to children's hands, Arch. Environ. Contam. Toxicol., 51, 2006, 157-163, DOI: 10.1007/s00244-005-7012y 
[6] Szabó Gy., Anthropogen Effects on Soils in Hungary, Oldenburger Geoökologishe Studien, 5, 2002, 188200

[7] Jiménez Ballesta R., Conde Bueno P., Martín Rubí J. A., Garcia Giménez R., Pedo-geochemical baseline content levels and soil quality reference values of trace elements in soils from the Mediterranean (Castilla La Mancha, Spain), Cent. Eur. J. Geosci., 2(4), 2010, 441-454, DOI: 10.2478/v10085-0100028-1

[8] Chen T. B., Wong J. W. C., Zhou H. Y., Wong M. H., Assessment of trace metal distribution and contamination in surface soils of Hong Kong, Environ. Pollut., 96, 1997, 61-68

[9] Christoforidis A., Stamatis N., Heavy metal contamination in street dust and roadside soil along the major national road in Kavala's region, Greece, Geoderma, 151, 2009, 257-263, DOI: 10.1016/j.geoderma.2009.04.016

[10] Bretzel F., Calderisi M., Metal contamination in urban soils of coastal Tuscany (Italy), Environ. Monit. Assess., 118, 2006, 319-335, DOI: 10.1007/s10661006-1495-5

[11] Li X. D., Lee S. L., Wong S. C., Shi W., Thornton I., The study of metal contamination in urban soils of Hong Kong using a GIS-based approach, Environ. Pollut., 129, 2004, 113-124

[12] Luo X. S., Yu S., Li X. D., Distribution, availability, and sources of trace metals in different particle size fractions of urban soils in Hong Kong: Implications for assessing the risk to human health, Environ. Pollut., 159, 2011, 1317-1326, DOI: 10.1016/j.envpol.2011.01.013

[13] Morton-Bermea O., Hernández-Álvarez E., GonzálezHernández G., Romero F., Assessment of heavy metal pollution in urban top-soils from the metropolitan area of Mexico City, J. Geochem. Explor., 101, 2009, 218-224

[14] Zawadzki J., Fabijańczyk P., The geostatistical reassessment of soil contamination with $\mathrm{Pb}$ in the Warsaw agglomeration, Int. J. Environ. Pollut., 35(1), 2008, 1-13

[15] Andersson M., Ottesen R. T., Langedal M., Monitoring in Trondheim, Norway. Geoderma, 156, 2010, 112118, DOI:10.1016/j.geoderma.2010.02.005

[16] Álvarez-Ayuso E., Otones V., Murciego A., GarcíaSánchez A., Santa Regina I., Zinc, cadmium and thallium distribution in soils and plants of an area impacted by sphalerite-bearing mine wastes, Geoderma, 207-208, 2013, 25-34, DOI: 10.1016/j.geoderma.2013.04.033

[17] Gjoka F., Tabaku V., Salillari I., Henningsen P. F.,
Duering R. A., Heavy metals in sediments from the Fani and Mati rivers (Albania). Carpath, J. Earth Env., 2, 2010, 153-160

[18] Horaicu C., Robu B., Florea F., Horaicu M. A., Heavy metal influence on an environment generated by the mining industry: the influence of copper, zinc, lead, manganese and silver on soil quality in the Mestecaniş area (Romania), Carpath, J. Earth Env., 5(2), 2010, 185-192

[19] Li X., Liu L., Wang Y., Luo G., Chen X., Yang $X$. , et al., Heavy metal contamination of urban soil in an old industrial city (Shenyang) in Northeast China, Geoderma, 192, 2013, 50-58, DOI: 10.1016/j.geoderma.2012.08.011

[20] Massas I., Ehaliotis C., Gerontidis S., Sarris E., Elevated heavy metal concentrations in top soils of an Aegean island (Greece): total and available forms, origin and distribution, Environ. Monit. Assess., 151, 2009, 105-116, DOI: 10.1007/s10661-008-0253-2

[21] Chirenje T., Ma L. Q., Reeves M., Szulczewski M., Lead distribution in near-surface soils of two Florida cities: Gainesville and Miami, Geoderma, 119, 2004, 113-120

[22] Gritsan N. P., Babiy A. P., Hazardous materials in the environment of Dnepropetrovsk Region (Ukraine), J. Hazard. Mater., A 76, 2000, 59-70

[23] MSZ-08-1722/3-1989, Investigations of soil. Methods for the determination of the soluble toxic element and heavy metal contents of the soil, A standard of the Department of Agriculture and Catering

[24] The joint decree nr. 6/2009 (IV. 14.) of KvVM-EüMFVM (the Hungarian Ministries of Environment, Healthcare and Agriculture, respectively) regarding the limit values and standard procedures to assess the pollution level, in order to protect the geological medium and ground-waters against pollution

[25] Dutch Target and Intervention Values, (the New Dutch List) Ministry of Housing, Spatial Planning and the Environment (VROM), 2000

[26] MSZ-08-0206-2-1978, The examination of certain chemical properties of the soil. Laboratory tests $(\mathrm{pH}$ value, phenol-phtalein alkalescence expressed in sodium, total water-soluble salt content, hydrolytic and exchange acidity, A standard of the Department of Agriculture and Catering

[27] MSZ-08-0205-1978, The examination of the physical and water economy properties of the soil, Hungarian Office of Standards, Budapest

[28] MSZ-08-0210-1977, Methods for the determination of the organic carbon content of the soil, A standard of the Department of Agriculture and Tourism 
[29] Podani J., Introduction to multivariate biological data exploration, Scientia, Budapest, 1997 (in Hungarian)

[30] Baxter M. J., Standardization and transformation in Principal Component Analysis, with applications to archaeometry Applied Statistics, 44, 1995, 513-517

[31] Jolliffe I. T., Principal Component Analysis, 2nd Edition, Springer, New York-Berlin-Heidelberg, 2002

[32] Kabacoff R. I., R in action, Manning. Shelter Island, 2011

[33] Quantum GIS Development Team, Quantum GIS Geographic Information System. Open Source Geospatial Foundation Project, 2012, http://qgis.osgeo.org

[34] Bennett J., Open Street Map - Be your own Cartographer, Packtlib, Birmingham, 2010

[35] Cohen J., Statistical power analysisemphCurr. Dir. Psychol., 1(3), 1992, 98-101

[36] Field A., Discovering statistics. SAGE Publications, London, 2009, 821

[37] Molnár, D. I., A megye városai. [The cities of the county]. In: Baranyi, B. (Ed.), Sub-Carpathia. The Regions of the Carpathian basin 11. H.A.Sc.-RKK Dialogue Campus Press, Pécs-Budapest, 2009, 241245 (in Hungarian)

[38] Galjan V. G. (Ed.), The Soils of Sub-Carpathia. Carpathian Press, Uzhhorod, 1969 (in Ukrainian)

[39] Krupskij N. K. (Ed.), The 1:200,000 scale soil map of the Ukrainian SSR Sub-Carpathia, 1969 (in Russian)

[40] Izsák T., Mineral Treasures, In: Baranyi, B. (Ed.), Sub-Carpathia. The Regions of the Carpathian basin 11. H.A.Sc.-RKK - Dialogue Campus Press, PécsBudapest, 2009, 118-123 (in Hungarian)

[41] Molnár J., Beregszászi járás, The Berehovo district, In: Baranyi, B. (Ed.), Sub-Carpathia. The Regions of the Carpathian basin 11. H.A.Sc.-RKK-Dialogue Campus Press, Pécs-Budapest, 2009, 269-273 (in Hungarian)

[42] Szabó Gy., Elek Z., Szabó Sz., Study of heavy metals in the soil-plant systememphCereal Res. Commun., 2008, 36, 403-406

[43] Szalai Z., Németh T., Influence of elementary land mosaics on chemical parameters of soil, Földrajzi Értesítő, 57(1-2), 2008, 135-146 (in Hungarian)

[44] Puskás I., Farsang A., The evaluation of the parameters indicating the level of anthropogenic effects in urban soils, In: Kertész Á., Dövényi Z., Kocsis K. (Eds.) Third Hungarian Conference on Geography: book of abstracts. Budapest, Geographical Research Institute, 2006, 186 (in Hungarian)

[45] Zawadzki J., Fabijańczyk P., Geostatistical evaluation of lead and zinc concentration in soils of an old mining area with complex land management, Int. J. Environ. Sci. Technol., 10, 2013, 729-742, DOI: 10.1007/s13762-012-0132-9

[46] Xia X., Chen X., Liu R., Liu H., Heavy metals in urban soils with various types of land use in Beijing, China, J. Hazard. Mater., 186, 2010, 2043-2050, DOI: 10.1016/j.jhazmat.2010.12.104

[47] Huang S. S., Liao Q. L., Hua M., Wu X. M., Bi K. S., Yan C. Y., et al., Survey of heavy metal pollution and assessment of agricultural soil in Yangzhong district, Jiangsu Province, China, Chemosphere, 67, 2007, 2148-2155, DOI: 10.1016/j.chemosphere.2006.12.043

[48] Imperato M., Adamo P., Naimo D., Arienzo M., Stanzione D., Violante P., Spatial distribution of heavy metals in urban soils of Naples city (Italy), Environ. Pollut., 124, 2003, 247-256

[49] Lark R. M., Scheib C., Land use and lead content in the soils of London. Geoderma, 2013, 209-210, 65-74

[50] Li H. B., Yu S., Li G. L., Deng H., Luo X. S., Contamination and source differentiation of $\mathrm{Pb}$ in park soils along an urban-rural gradient in Shanghai, Environ. Pollut., 159, 2011, 3536-3544, DOI: 10.1016/j.envpol.2011.08.013

[51] Shi G. T., Chen Z. L., Xu S. Y., Zhang J., Wang L., Bi C. J., et al., Potentially toxic metal contamination of urban soils and roadside dust in Shanghai, China, Environ. Pollut., 156, 2008, 251-260, DOI: 10.1016/j.envpol.2008.02.027

[52] Khan S., Khan M. A., Rehman S., Lead and cadmium contamination of different roadside soils and plants in Peshawar city, Pakistan. Pedosphere, 21 (3), 2011, 351-357, DOI: 10.1016/S1002-0160(11)60135-5

[53] The decree nr. 2786-III. of Ukraine, in force from 2001.11.15., regarding the prohibition of importing and selling/distributing leaded gasoline or any leadcontaining additives, in Ukraine

[54] Sipos P., Distribution and sorption of potentially toxic metals in four forest soils from Hungary, Cent. Eur. J. Geosci., 1(2), 2009, 183-192, DOI: 10.2478/v10085009-0009-4

[55] Sipos P., Németh T., May Z., Szalai Z., Accumulation of trace elements in the Fe-rich nodules in a neutralslightly alkaline floodplain soil. Carpath, J. Earth Env., 6(1), 2011, 13-22

[56] Szabó Sz., Szabó Gy., Bihari Á., Effects of acid loadings on heavy metal mobilization in Cambisols, Annales Geographicae, XL(2), 2007, Vilnius, Lithuania, 72-79

[57] Bakirdere S., Yaman M., Determination of lead, cadmium and copper in roadside soil and plants in Elazig, Turkey, Environ. Monit. Assess., 136, 2008, 401-410, DOI: 10.1007/s10661-007-9695-1 
[58] Alloway B. J., Heavy metals in soils, second ed. Blackie Academic and Professional, London, 1995

[59] Sipos P., Single element and competitive sorption of copper, zinc and lead onto a Luvisol profile, Cent. Eur. J. Geosci., 1(4), 2009, 404-415, DOI: 10.2478/v10085-009-0035-2

[60] Szopka K., Karczewska A., Jezierski P., Kabata C., Spatial distribution of lead in the surface layers of mountain forest soils, an example from the Karkonosze National Park, Poland, Geoderma, 192, 2013, 259-268, DOI: 10.1016/j.geoderma.2012.08.022

[61] Huang Z., Pan X. D., Wu P. G., Han J. L., Chen Q., Heavy metals in vegetables and the health risk to population in Zhejiang, China, Food Control, 36, 2014, 248-252

[62] Kampouroglou E. E., Economou-Eliopoulos M., Natural Contamination by As and Heavy Metals in
Soil, Their Bio-Accumulation and Potential Sources: the Case of a Travertine Limestone Quarry, Greece, Cent. Eur. J. Geosci., 5(1), 2013, 174-188, DOI: 10.2478/s13533-012-0122-y

[63] Puskás, I., Farsang, A., Evaluation of Humanimpacted Soils in Szeged (SE Hungary) with Special Emphasis on Physical, Chemical and Biological Properties, In: Dazzi C., Costantini E. (ed.) The soils of tomorrow - Changing soil in a Changing World, 2008, 117-147

[64] Szegedi S., Heavy metal loads in the soil of Debrecen, Acta Geographica Debrecina Landscape and Environment, 1(1), 2007, 57-67

[65] Szolnoki Z., Farsang A., Puskás I., Cumulative impacts of human activities on urban garden soils: origin and accumulation of metals, Environ. Pollut., 177, 2013, 106-115, DOI: 10.1016/j.envpol.2013.02.007 